\title{
Repeated occurrence of palaeo-wildfires during deposition of the Bahariya Formation (early Cenomanian) of Egypt
}

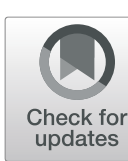

Haytham El Atfy', Tarek Anan ${ }^{1}$, André Jasper ${ }^{2,3}$ and Dieter Uhl $1^{3,4^{*}}$

\begin{abstract}
The Upper Cretaceous (early Cenomanian) Bahariya Formation of Egypt has an outstanding reputation for its wealth of vertebrate remains, including a variety of iconic dinosaurs, like the carnivorous Spinosaurus and Carcharodontosaurus, as well as the herbivorous Aegyptosaurus and Paralititan. Besides these dinosaur fossils, the Bahariya Formation yielded also a wealth of invertebrate and plant remains, but even today many aspects concerning the continental palaeoenvironments reflected in these deposits (including the occurrence of palaeo-wildfires) have not been studied in detail. So far six distinct macro-charcoal bearing levels could be identified within the type section of the Bahariya Formation at Gabal El Dist profile, one of the most prolific outcrops of this formation in terms of fossil occurrence located in the north of the Bahariya Oasis, Western Desert, Egypt. Most of the charcoal investigated by means of SEM originates from ferns, pointing to a considerable proportion of this plant group within the palaeo-ecosystems that experienced fires. Gymnosperms and (putative) angiosperms have less frequently been identified. The collected data present evidence that the landscapes at the northern shores of Gondwana repeatedly experienced palaeo-wildfires, adding extra proof to previous statements that the Late Cretaceous was a fiery world on a global scale.
\end{abstract}

Keywords: Bahariya Oasis, Gabal El Dist, Charcoal, Wildfire, Dinosaurs, Upper Cretaceous, Early Cenomanian, Egypt

\section{Introduction}

For almost a century different proxies, such as charcoal, coal macerals like fusinite and semifusinite, as well as pyrogenic polyaromatic hydrocarbons have widely been used to reconstruct the history of palaeo-wildfires throughout the Earth's deep time history (e.g. Potonié 1929; Harris 1958; Alvin 1974; Scott 2000, 2010; Scott et al. 2014). Numerous studies have demonstrated that wildfires were integral agents of disturbance in many continental ecosystems ever since the Silurian (e.g. Scott 2000, 2010; Scott et al. 2014; Jasper et al. 2017; Pole et al. 2018; and citations therein). Nevertheless there are still large stratigraphic and geographic gaps in the knowledge about pre-Quaternary wildfires (e.g. Abu Hamad et al. 2012; Brown et al. 2012).

The Cretaceous is widely regarded as a "high-fire" period in Earth's history (e.g. Brown et al. 2012; Scott

\footnotetext{
* Correspondence: dieter.uhl@senckenberg.de

${ }^{3}$ Senckenberg Research Institute and Natural History Museum, 60325

Frankfurt am Main, Germany

${ }^{4}$ Senckenberg Centre for Human Evolution and Palaeoenvironment,

Tübingen University, 72076 Tübingen, Germany

Full list of author information is available at the end of the article
}

et al. 2014) and recently it has been argued that the frequent and intense fires occurring during large parts of the Cretaceous may have played an important role in the evolution of angiosperms and angiosperm dominated vegetation (e.g. Bond and Scott 2010; Brown et al. 2012; Belcher and Hudspith 2017). However, as summarized by Brown et al. (2012), the majority of published records for Cretaceous fires comes from the northern continents (i.e. North America, Europe, Asia) while there are large geographic and stratigraphic gaps on the southern continents, formerly parts of Gondwana.

In the last few years, a number of studies (e.g. Manfroi et al. 2015; Muir et al. 2015; Abu Hamad et al. 2016a, 2016b; Carpenter et al. 2016; dos Santos et al. 2016; El Atfy et al. 2016; Martill et al. 2012; Lima et al. 2019) have already demonstrated that the Cretaceous wildfires were more frequent on the southern continents than previously reported in the literature (e.g. Brown et al. 2012). However, compared to records from the northern continents still considerably less is known about the 
Cretaceous fires from the southern continents, including the entirety of Africa.

The occurrence of macro-charcoal in sediments of the Bahariya Formation at the Bahariya Oasis, Egypt has previously been mentioned by a number of authors (e.g. Dominik 1985; Nothdurft et al. 2002), unfortunately without providing any conclusive evidence (sensu Scott 2000, 2010) that the material really represents charcoal, and therefore it is not clear whether these reports can be used as evidence for the occurrence of wildfires or not. Here we present such evidence for the repeated occurrence of palaeo-wildfires during deposition of the Bahariya Formation in the form of macro-charcoal originating from six distinct levels at the Gabal El Dist profile at the Bahariya Oasis. This evidence confirms the previous claims about the occurrence of charcoal in the Bahariya Formation, and adds reliable information on the so far only known occurrence of Cenomanian palaeo-wildfires all over Africa.

\section{Geology, palaeontology and stratigraphy}

The Bahariya Oasis is situated in a morphological depression of an Eocene Limestone Plateau, where Cretaceous sediments are exposed. It is located about $340 \mathrm{~km}$ southwest of Cairo in the Western Desert of Egypt (Fig. 1). Within the area of the Bahariya Oasis, the oldest sediments exposed at the surface belong to the clastic unit of the Bahariya Formation, which is unconformably overlain by the late Campanian Hefuf Formation (Werner, 1990). The Bahariya Formation was defined by Said (1962) and El Akkad and Issawi (1963). According to Klitzsch and Hermina (1989), the Bahariya Formation at its type locality (and near our studied area) is lithologically composed of fluviatile sandstone and siltstone in the lower part, grading upwards into alternating beds of estuarine sandstone and shale, especially in the Abu Roash area.

Lithostratigraphically, the Bahariya Formation has been subdivided into two members: the lower Gebel Ghorabi Member (fluviatile sandstone); and, the upper Gebel Dist Member, which is strongly affected by tides with some intercalations of lagoonal origin, made up of intercalations of partly glauconitic sandstone, siltstone and claystones (Dominik 1985). Some authors (e.g. Dominik 1985) also include the overlying El Heiz Formation as a third member, which is composed of calcareous or siliceous sandstones and claystones that represent gradual regression and which is of lagoonal and supratidal origin. However, in the current study we treat this rock unit as El Heiz Formation, following El Akkad and Issawi (1963) and others, as this nomenclature is widely accepted.

The fossil content of the Bahariya Formation is well known for its outstanding record of vertebrate remains, including a variety of iconic dinosaurs, like the carnivorous Spinosaurus and Carcharodontosaurus, as well as the herbivorous Aegyptosaurus and Paralititan (e.g. Stromer 1915,
1931, 1932; Smith et al. 2001; Nothdurft et al. 2002). However, besides dinosaurs and other vertebrates as well as invertebrates (e.g. Stromer 1936; Nothdurft et al. 2002; Schweitzer et al. 2003), the Bahariya Formation provided also a wealth of fossil plants in different preservational states (e.g, Kräusel 1924, 1939; Hirmer 1925; Lejal-Nicol 1987, 1990; Lejal-Nicol and Dominik 1990; El-Saadawi et al. 2016).

The presence of vertebrate and plant remains, especially in the upper part of the Gebel Dist Member (Dominik 1985), points to a Cenomanian age for the formation (Schaal 1984; Dominik 1985; Lejal-Nicol 1987). The fossil content includes terrestrial vertebrates like aquatic lungfishes, turtles, crocodiles, dinosaurs, marine vertebrates like sharks, plesiosaurs and the sea serpent Symoliophis sp., as well as ammonites, lamellibranchiates and mangrovedwelling crabs (e.g. Schaal 1984; Dominik 1985; Werner 1989; Smith et al. 2001; Schweitzer et al. 2003). Plant remains include Paradoxopteris stromeri, Weichselia reticulata, Nelumbites, Cornaephyllum, Dipterocarpophyllum, Magnoliaephyllum, Ficophyllum, Laurophyllum, Araliaephyllum, Salix and Rogersia (e.g. Kräusel 1924, 1939; Hirmer 1925; Lejal-Nicol 1987, 1990; Lejal-Nicol and Dominik 1990; El-Saadawi et al. 2016). All these findings represented a unique source of information about the Late Cretaceous North African continental palaeoecosystems, although there are still many aspects of these ecosystems which have so far not been studied in sufficient detail.

\section{Material and methods}

During field work in 2016, a total of 50 samples (labelled D1-D50) were taken from the Gabal El Dist profile for further analysis (Fig. 2). All samples were checked for the presence of macroscopically recognizable charcoal and if present, charcoal samples were extracted mechanically from the sediment with the aid of preparation needles and tweezers under a binocular microscope in the laboratory.

Due to the very fragile nature of the charcoal specimens, they could not be cleaned further with acids to remove adhering mineral remains, as even very careful treatment has led to the total fragmentation of comparable material into even smaller fragments. The samples collected at Gabal El Dist profile are stored in the collection of the Department of Geology, Mansoura University (Egypt). Samples prepared for SEM are stored in the collection of the Senckenberg Forschungsinstitut und Naturmuseum Frankfurt (Germany).

Samples were mounted on standard stubs with LeitC (Plano, Münster, Germany), and subsequently examined with the aid of a JEOL JSM 6490 LV Scanning Electron Microscope (SEM; accelerator current $20 \mathrm{kV}$ ) at the Senckenberg Forschungsinstitut und Naturmuseum Frankfurt (Germany). 


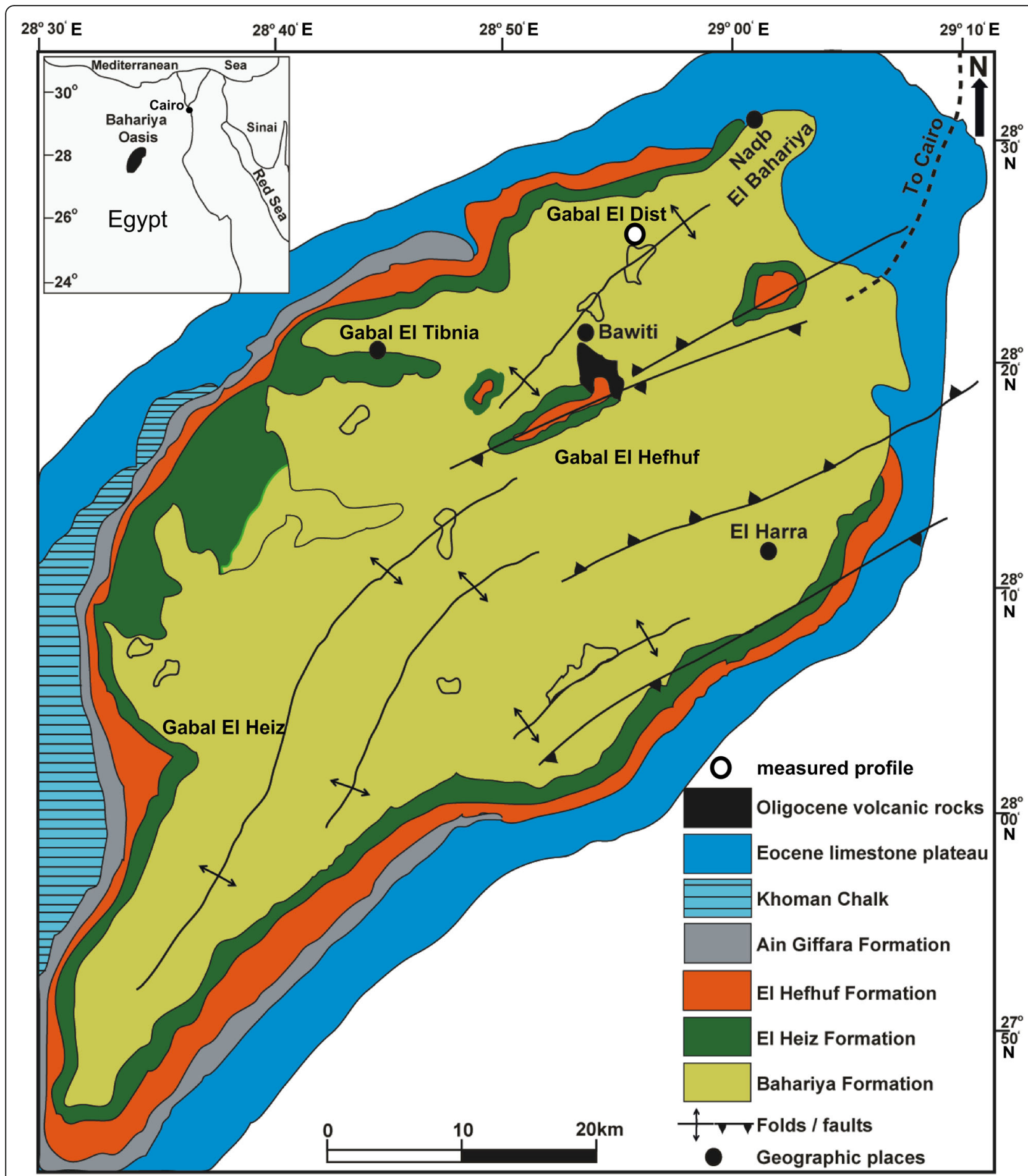

Fig. 1 Geologic and geographic map of the Bahariya Oasis, Western Desert, Egypt (modified after El Akkad and Issawi 1963)

Macro-charcoal was recovered from 6 levels of the studied profile, labelled here in ascending order as "Charcoal level" (Chl) 1 to 6. In Chl 1 (sample D2), charcoal fragments occur in grey, massive, gypsiferous, slope forming clay. This level corresponds to the so called "dinosaur bed", from which numerous vertebrate remains have been recovered during the last century (Dominik 1985). Charcoal fragments are between $2 \times 3$ $\mathrm{mm}$ and $10 \times 10 \mathrm{~mm}$ large, with rounded edges. A total of 3 pieces of charcoal has been analysed by SEM. 


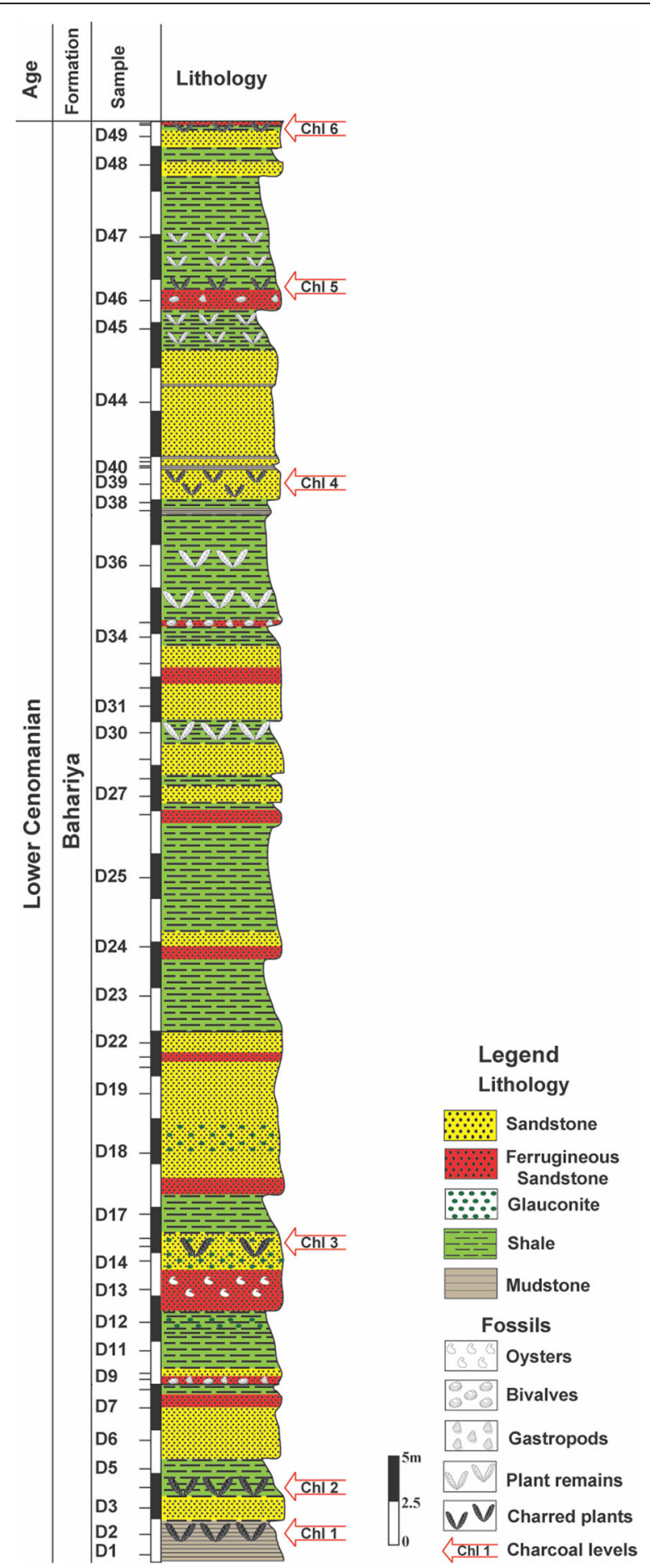

Fig. 2 Lithostratigraphy of the measured profile of the Gebel Dist Member of the Bahariya Formation at Gabal El Dist, Western Desert, Egypt

In Chl 2 (sample D4), charcoal fragments occur in a grey, fissile, gypsiferous, moderately hard shale, which forms slopes. They are between $1 \times 1 \mathrm{~mm}$ and $4 \times 4 \mathrm{~mm}$ large, with slightly rounded edges. A single piece of charcoal could be analysed by means of SEM. The charcoal from this level is heavily crushed due to sediment compaction and no taxonomically meaningful anatomical details can be observed, which would be necessary for any further interpretation.

In Chl 3 (sample D15), charcoal fragments occur in varicoloured green and yellow, slightly hard to friable, glauconitic sandstone, which forms cliffs. They range from tiny fragments (smaller than $1 \times 1 \mathrm{~mm}$ ) up to $10 \times 15 \mathrm{~mm}$ large fragments, with rounded edges in large fragments. Charcoal is rather abundant in this level, as compared to the other levels, and only slightly compressed. A total of 15 pieces of charcoal has been analysed by means of SEM.

In Chl 4 (sample D39), charcoal fragments occur in a grey, moderately hard, gypsiferous sandstone, which forms cliffs. They are between $2 \times 2 \mathrm{~mm}$ and $10 \times 10 \mathrm{~mm}$ large, with slightly rounded edges. A single piece of charcoal has been analysed by means of SEM.

In Chl 5 (sample D47), charcoal fragments occur in a dark grey to black, fissile, gypsiferous shale, containing plant remains, which forms slopes. They are between $2 \times$ $2 \mathrm{~mm}$ and $5 \times 10 \mathrm{~mm}$ large, with sharp edges. A total of 2 pieces of charcoal have been analysed by means of SEM.

In Chl 6 (sample D50), charcoal fragments occur in dark grey, fissile, gypsiferous shale units, topped by ferruginous, slope forming sandstone. They are between $1 \times 1 \mathrm{~mm}$ and $5 \times 15 \mathrm{~mm}$ large, with rounded edges. A single piece of charcoal was analysed by means of SEM.

\section{Results}

\subsection{Preservation}

The specimens from all six levels investigated for this study exhibit black streak, silky lustre, as well as threedimensionally and well preserved anatomical details (Figs. 3, 4, 5, 6) and homogenized cell walls under the SEM (e.g. Fig. 4a). These features are considered as diagnostic for charcoal (e.g. Jones and Chaloner 1991; Scott 2000, 2010) and thus represent direct evidence for the repeated occurrence of palaeo-wildfires during deposition of the Cenomanian Bahariya Formation at Gabal El Dist profile, Western Desert, Egypt.

Charcoal from Chl 2 has heavily been compacted and shattered, showing limited anatomical details, which would be necessary for further interpretations of the taxonomic affiliation of charred source plants and thus the potential source vegetation. In some specimens from Chls 1, 3 and 6, fungal hyphae occur on tracheid walls (Fig. 4b, c), occasionally growing through pit apertures (Fig. 4c). One specimen from Chl 1 exhibits large cavities in the center of the cell walls, which can be interpreted as the result of microbial decay by so far unidentified microorganisms prior to charring (Fig. 4c-f) (cf. El Atfy et al. 2017). These cavities also include 

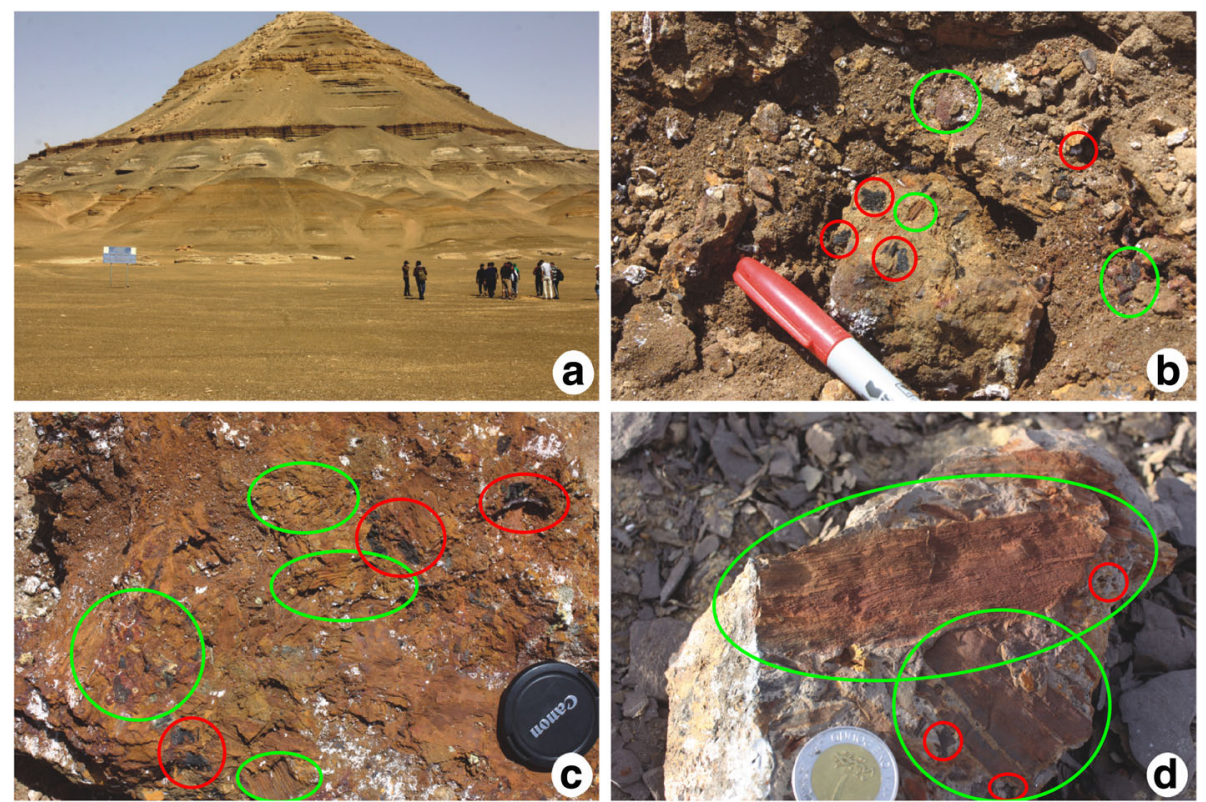

Fig. 3 Field photographs from Gabal El Dist profile near the Bahariya Oasis in Western Desert of Egypt. a General view of Gabal El Dist profile which is the type locality of the Bahariya Formation; height of the persons in the foreground is approx. $1.8 \mathrm{~m}$; $\mathbf{b}$ Plant remains (green circles), including macro-charcoal (red circles), in very fine sandstone; thickness of the pen is $1.5 \mathrm{~cm}$; c Plant remains (green circles), including macrocharcoal (red circles), in shale; diameter of the lens cap is $5.8 \mathrm{~cm}$; d Plant remains (green circles), including macro-charcoal (red circles), in shale; diameter of the coin is $2.5 \mathrm{~cm}$

putative fungal remains (Fig. 4e), and numerous threedimensionally preserved, filamentous structures of unknown origin (Fig. 4f).

\subsection{Anatomy and taxonomy}

In most charcoal levels, charcoal fragments are either too small or heavily compressed and thus no anatomical details of any taxonomic value can be obtained from these specimens. However, some specimens from Chl 5 and $\mathrm{Chl} 6$, as well as all specimens from Chl 3 show enough anatomical details to enable at least some general taxonomic interpretation. So far, these charcoal specimens can be assigned to ferns, a gymnosperm and a (putative) angiosperm.

\subsubsection{Fern}

Charcoal fragments assignable to ferns have so far only been identified within $\mathrm{Chl} \mathrm{3,} \mathrm{but} \mathrm{here} \mathrm{they} \mathrm{are} \mathrm{abundant.}$ Charcoal specimens consist of sclerenchymatic fibres (Fig. 5a, b), tracheids (30-70 $\mu \mathrm{m}$ wide) with scalariform pitting (Fig. 5d, f) and parenchymatic cells (Fig. 5c).

The observed anatomical details in these specimens are in agreement with the anatomy of Paradoxopteris stromeri Hirmer (cf. Hirmer 1925, 1927; Edwards 1933; Koeniguer 1966), which has previously been described from the Bahariya Formation at the Bahariya Oasis (e.g. Hirmer 1925, 1927; Kräusel 1939; El-Saadawi et al. 2016). Silicified remains belonging to this taxon occur frequently in the basal most horizons at Gabal El Dist (Stromer 1914; Hirmer 1925). This taxon represents the rachis of the mattoniaceous fern Weichselia reticulata (e.g. Schuster 1930; Edwards 1933), which also occurs in the Bahariya Formation at Bahariya Oasis (e.g. Hirmer 1925; Kräusel 1939; El-Saadawi et al. 2016). However, due to the fragmentary nature of the charcoal specimens, a definitive assignment to either of these taxa is not possible, although it seems very likely that at least some of the charcoal specimens belong to the same source plant as these taxa. A comparable co-occurrence of anatomically comparable, charred fern rachisfragments and Weichselia reticulata fronds has previously been described from other Cretaceous localities (e.g. Abu Hamad et al. 2016a).

Ferns were abundant and diverse in the Cenomanian habitats on the northern shore of Gondwana, as indicated by palynological studies. Based on spores, a number of fern families, i.e. Cyatheaceae/Dicksoniaceae, Osmundaceae, Matoniaceae/Dipteridaceae, Gleicheniaceae and Schizaeaceae, were known from the Bahariya Formation (e.g. Abdel-Kireem et al. 1996; Ibrahim 2002; El Atfy 2011).

\subsubsection{Gymnosperm}

Only a single specimen of charcoal from Chl 6 can unequivocally be assigned to the gymnosperms. It consists of pycnoxylic wood (Fig. 6a) with abundant rays (Fig. 6b). 

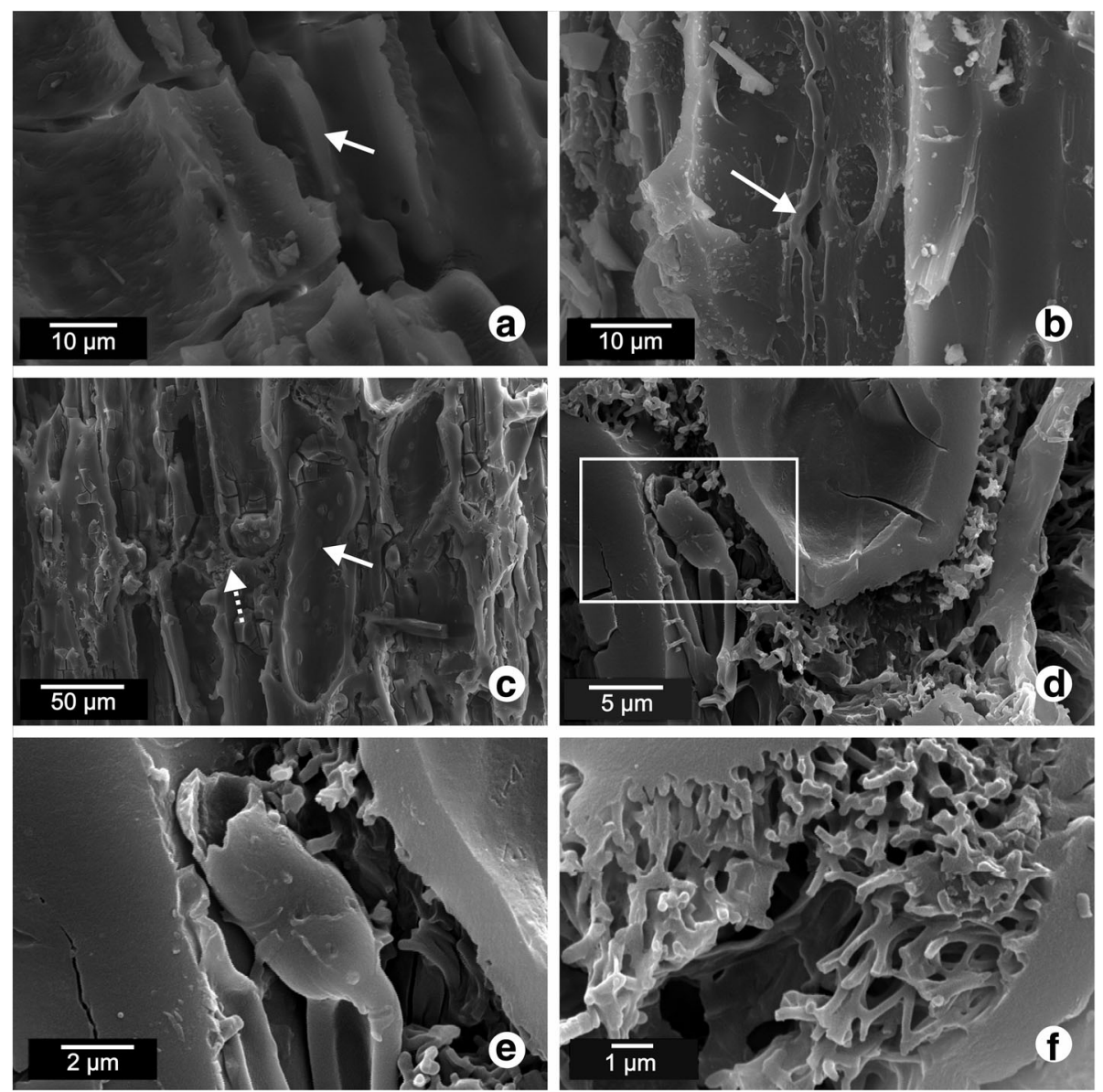

Fig. 4 SEM images of macro-charcoal from the Bahariya Formation (Gabal El Dist profile at the Bahariya Oasis). a Charcoal from Chl 2 with homogenized cell walls (specimen: SMB 16-192-BAH); b Tracheid of a charred fern from Chl 3 with fungal hyphae (arrow) (specimen: SMB 16202-BAH); c Partly decayed charcoal from Chl 1 exhibiting parenchymatic (?) cells with fungal hyphae (solid arrow) and cavities in the center of the cell walls (dotted arrow) (specimen: SMB 13-18-BAH); d A close-up of a cavity (specimen: SMB 13-18-BAH); e Zoomed area of the box in d showing some fungal (?) remains; $\mathbf{f}$ Detail of same specimen as in $\mathbf{d}$, showing numerous three-dimensionally preserved, filamentous structures of unknown origin

Rays are either 2 (Fig. 6d) or 4-8 cells (Fig. 6f) high, with one (or rarely two) pits on cross-fields (Fig. 6e, f). Tracheids are $\sim 8-18 \mu \mathrm{m}$ wide (Fig. $6 \mathrm{~d}$ ). Pits on radial tracheid walls are uni-seriate and touching, with relatively large apertures. The same can be seen in cross-field-pits which resemble taxodioid or cupressoid pits. As the form of pit-apertures is easily altered during charring (Gerards et al. 2007), it is not clear whether this observation represents the primary state of the apertures or a charring artefact. Due to these alterations and the fragmentary nature of the specimen, it is not possible to provide a more specific taxonomic affiliation.

Kräusel (1939) compared silicified gymnosperm wood from the Bahariya Formation at Bahariya Oasis with Dadoxylon aegyptiacum Unger. Otherwise gymnosperm remains seem to be rather rare in the macroflora of the Bahariya Formation. In contrast pollen assignable to a number of different gymnosperm groups, including conifers, cycads and Gnetales, are abundant and diverse in the sediments of the Bahariya Formation (e.g. AbdelKireem et al. 1996; Ibrahim 2002; El Atfy 2011).

\subsection{3 (Putative) Angiosperm}

In some charcoal levels (Chls 1,4 and 5), a few charcoal fragments occur, which might be related to angiosperms. However, in most levels these fragments are too small to allow for an unequivocal decision whether they really belong to angiosperms or not. Only specimens from Chl 5 show enough anatomical details allowing for at least some anatomical description.

The matrix of the wood consists of rather small fibres and/or tracheids and parenchymatic cells (Fig. 7a-e). Vessels (?) are around $50 \mu \mathrm{m}$ wide, with scalariform perforation plates (Fig. 7a-c). Intervessel pits on vessel walls 

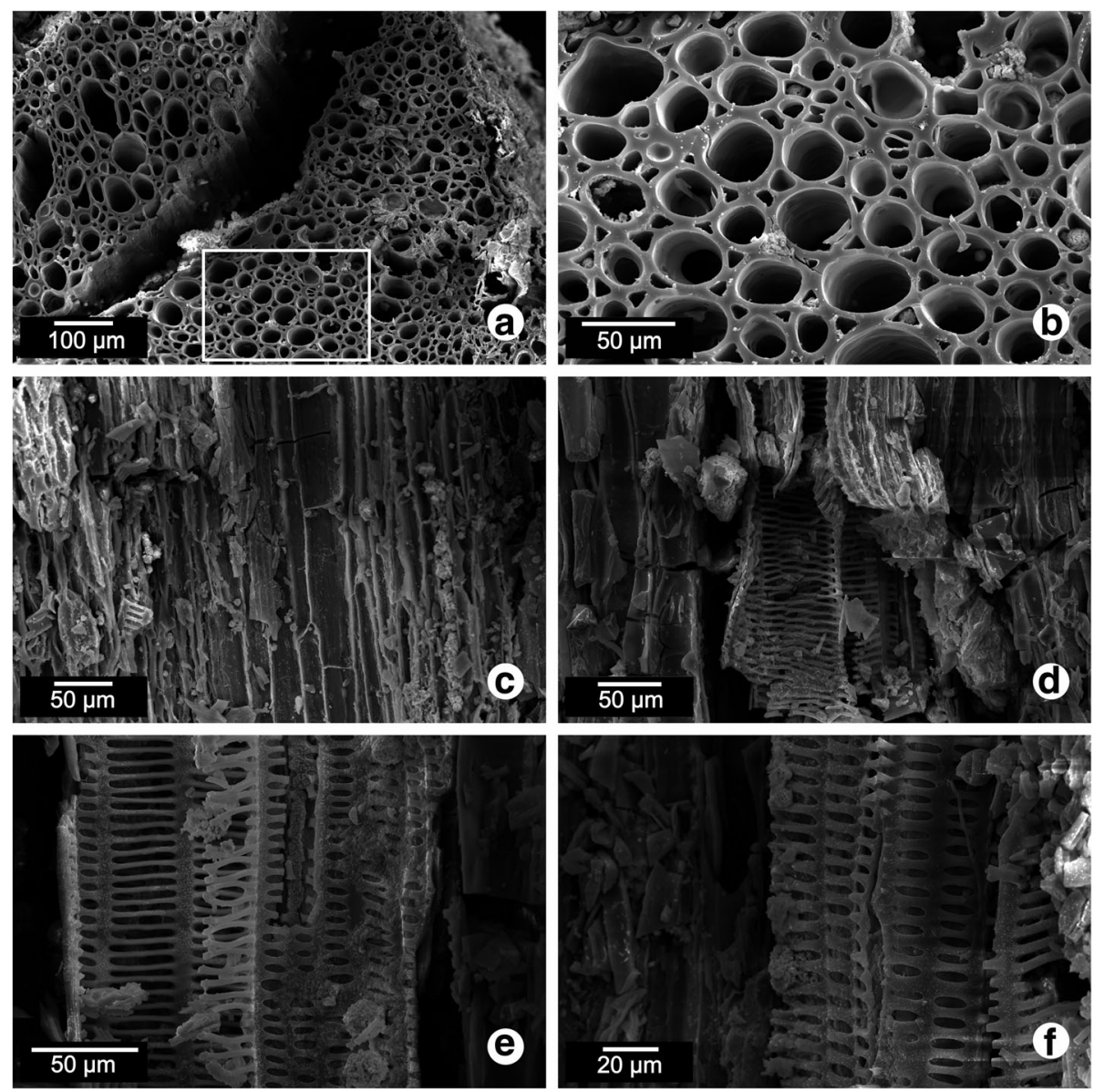

Fig. 5 SEM images of charred ferns from the Bahariya Formation (Chl 3 of Gabal El Dist profile at the Bahariya Oasis). a Overview of cross-section of fern xylem (specimen: SMB 16-200-BAH); b Zoomed area of the box in a, showing the roundish shape of the tracheids in cross-section; $\mathbf{c}$ Axial parenchyma (specimen: SMB 16-202-BAH); d Tracheid with scalariform pitting (specimen: SMB 16-201-BAH); e Tracheid with scalariform pitting (specimen: SMB 16-201-BAH); f Tracheid with scalariform pitting (specimen: SMB 16-200-BAH)

are scalariform (Fig. 7a-c). Vessels are surrounded by vasicentric tracheids (Fig. $7 \mathrm{~d}$-f). Due to the fragmentary nature of all specimens, it is not possible to provide a more specific taxonomic affiliation than to state that these remains probably represent angiosperms.

According to Kräusel (1939), silicified wood of Evodioxylon intermedium Kräusel, a putative Rutaceae, occurs in the Bahariya Formation at Bahariya Oasis. Additionally a number of angiosperm taxa based on leaf remains have been cited in the literature (e.g. Kräusel 1924, 1939; Lejal-Nicol 1987, 1990; Lejal-Nicol and Dominik 1990), but these remains are in urgent need of a modern taxonomic revision. A number of pollen taxa assignable to angiosperms have also been reported from the Bahariya Formation (e.g. Abdel-Kireem et al. 1996; Ibrahim 2002; El Atfy 2011).

\section{Discussion}

The occurrence of putative charcoal, in form of black and opaque phytoclasts, has repeatedly been mentioned by palynological studies of sediments attributed to the Bahariya Formation from different subsurface wells within the North Western Desert (e.g. Tahoun and Mohamed 2013), but none of this material has so far been figured and thus it is not clear whether it really represents charcoal or not. Additionally, Dominik (1985) and Nothdurft et al. (2002) mentioned the occurrence of macroscopic plant fragments, which might represent charcoal within sediments of the Bahariya Formation at the Bahariya Oasis. However, also these authors conducted no in depth analysis of these remains, to provide proof for a pyrogenic origin of the material mentioned by them. The charcoal presented here (including the material studied by El Afty et al. 2017, for taphonomic purposes), represents unequivocal proof for the (previously only assumed) occurrence of palaeowildfires during deposition of the sediments of the early Cenomanian Bahariya Formation in Egypt.

Additionally our results provide further evidence for the globally widespread occurrence of wildfires during large parts of the Cretaceous (cf. Brown et al. 2012 and citations 

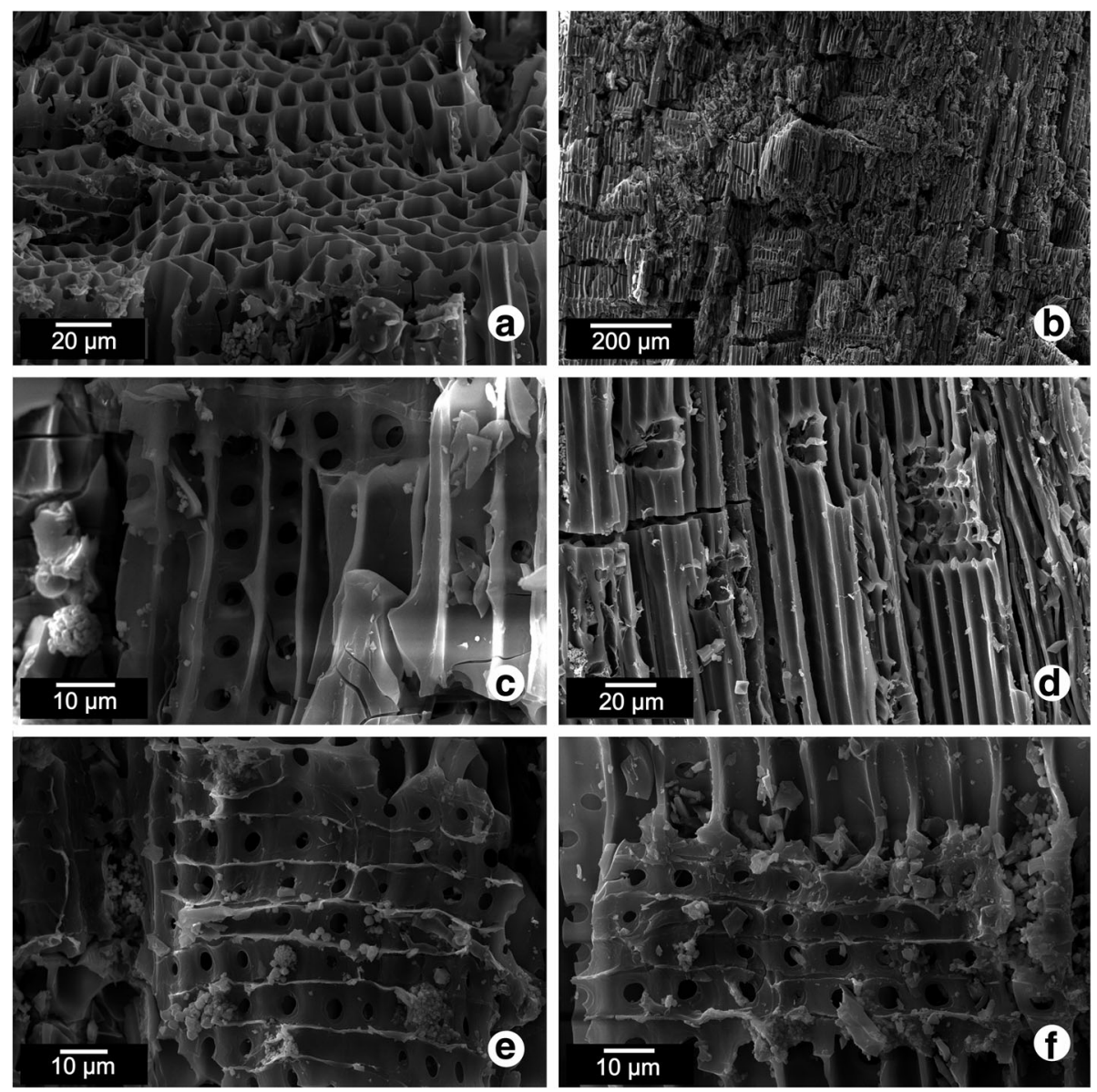

Fig. 6 SEM images of gymnosperm charcoal from the Bahariya Formation (Chl 6 of Gabal El Dist profile at the Bahariya Oasis). a Cross-section showing more or less rectangular cross-section of tracheids (specimen: SMB 16-197-BAH); b Overview of radial section (specimen: SMB 16-197BAH); c Uniseriate pits on radial tracheid walls (specimen: SMB 16-197-BAH); d Rays in semi-oblique radial view (specimen: SMB 16-197-BAH); e Detail of ray in radial view with cross-field pitting (specimen: SMB 16-197-BAH); $\mathbf{f}$ Detail of ray in radial view with cross-field pitting (specimen: SMB 16-197-BAH)

therein). It represents only the fourth Cenomanian report for the entirety of Gondwana (Table 1; Fig. 8) and constitutes the first description of evidence for repeated palaeowildfires in a single profile for that palaeo-continent. This demonstrates that such fire-events repeatedly affected the landscapes at the northern shore of Africa during this age and that they were important factors in palaeoenvironments in which iconic dinosaurs, like the carnivorous Spinosaurus and Carcharodontosaurus, roamed. However, at the moment it is not clear, how these dinosaurs were affected by these recurrent wildfires, but it seems at least reasonable to assume that fires may have influenced the animals living in the habitats experiencing the wildfires, either through the direct negative effects of fire and heat or indirectly through destruction of the vegetation as primary source of food, shelter etc.

The occurrence of charred fern remains as well as gymnosperm and (putative) angiosperm charcoal in different levels (but so far not together in the same level) suggests that maybe different vegetation types were affected by fires during deposition of the Bahariya Formation. Of particular interest is the abundant charcoal from Chl 3, as this material seems to consist only of charcoal derived from ferns comparable to Paradoxopteris/Weichselia reticulata. Similar accumulations of charred fern remains attributed to Paradoxopteris/Weichselia reticulata, are known from other Cretaceous deposits (e.g. Harris 1958, 1981; Alvin 1974; Brown et al. 2012; Sender et al. 2015; Abu Hamad et al. 2016a), and experimental work on different potential sources of fuel for Cretaceous fires showed that many ferns are highly flammable and may support rapidly spreading fires (e.g. Harris 1981; Belcher and Hudspith 2017). Under the high-oxygen atmosphere of the Late Cretaceous, not only the potential to be ignited would even be higher than today (e.g. Belcher and McElwain 2008; Belcher et al. 2010) but also the intensity of such fern fuelled fires (Belcher and Hudspith 2017). This higher flammability of Cretaceous vegetation is also 

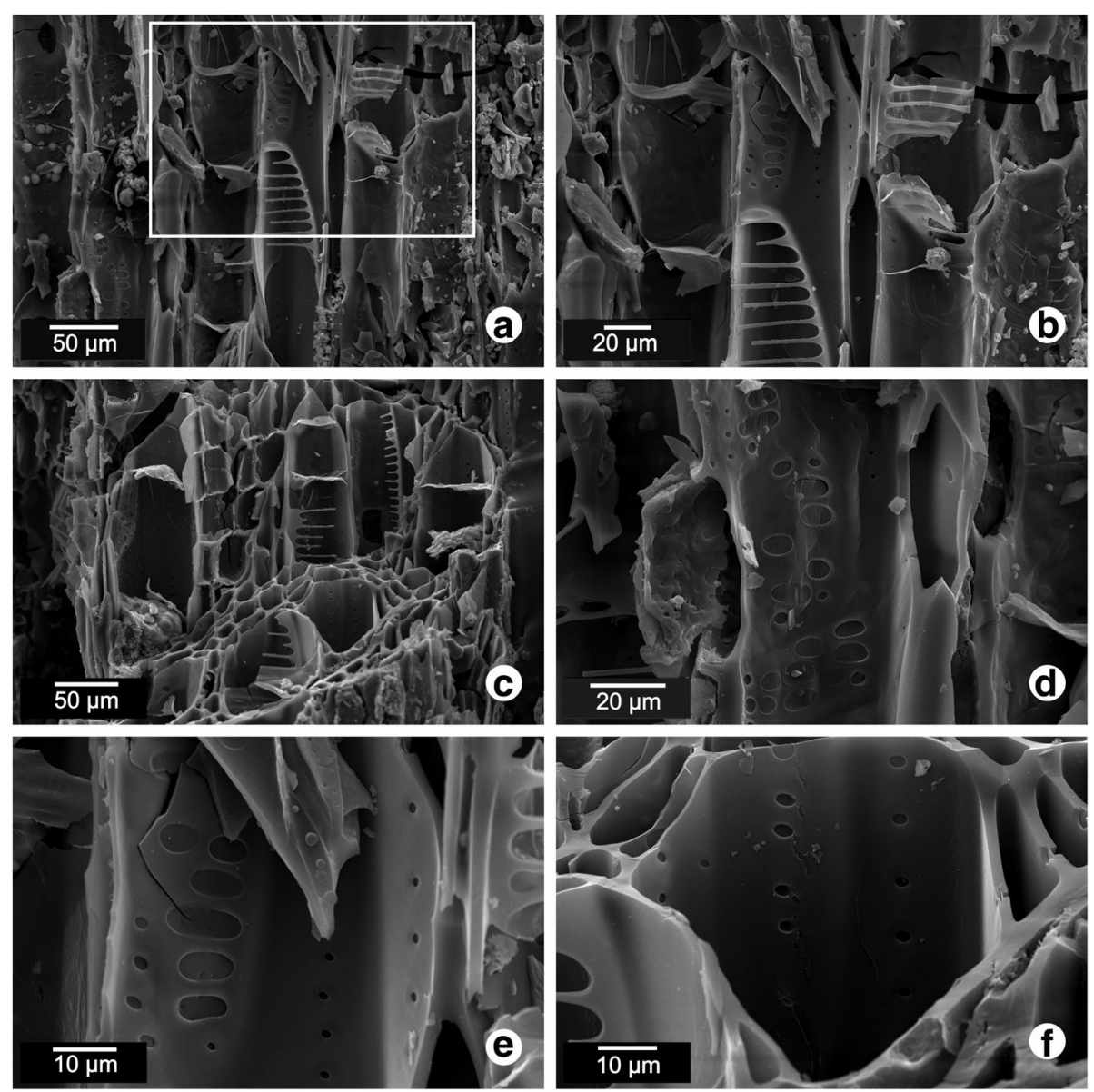

Fig. 7 SEM images of angiosperm-like charcoal from the Bahariya Formation (Chl 5 of Gabal El Dist profile at the Bahariya Oasis). a Vessels with scalariform sieve-plate and axial parenchyma (specimen: SMB 16-196-BAH); $\mathbf{b}$ Zoomed area of the box in $\mathbf{a}$, showing scalariform perforation plate and pitting on vessel wall; c Overview with vessels, vasicentric tracheids and parenchyma (specimen: SMB 16-196-BAH); d Detail of pitting on vessel wall (specimen: SMB 16-196-BAH); e Detail of pitting on vessel wall consisting of large scalariform intervessel pits and small uniseriate pits in cell walls shared with tracheids (specimen: SMB 16-196-BAH); $\mathbf{f}$ Detail of pitting on vessel wall consisting of small uniseriate pits in cell walls shared with tracheids (specimen: SMB 16-196-BAH)

reflected in the relatively high concentrations of pyrogenic inertinites in numerous coals from this period (e.g. Diessel 2010; Glasspool and Scott 2010).

Based on plant macroremains (mainly impressions, root traces and permineralised remains), Lacovara et al. (2003) and El-Saadawi et al. (2016) interpreted the palaeoflora of the Bahariya Formation as mainly representing a mangrove, an interpretation supported by the occurrence of typical mangrove-dwelling crabs (Schweitzer et al. 2003). It is possible that the charred ferns from $\mathrm{Chl} 3$ were growing in a comparable coastal (mangrove or mangrove-like) ecosystem, as it has been assumed for another deposit also containing abundant fern-charcoal probably related to Paradoxopteris from the Early Cretaceous (Barremian) of Jordan (Abu Hamad et al. 2016a). A number of authors (e.g. Retallack and Dilcher 1981; Shinaq and Bandel 1998; Lacovara et al. 2003) interpreted Weichselia/Paradoxopteris as a typical constituent of such a mangrove-like vegetation type, flourishing during the Early-early Late Cretaceous. However, as the charcoal from this sandstone level at Bahariya Oasis has to be regarded as allochthonous, an origin from mangrove-like vegetation must remain speculative at the moment.

The occurrence of charcoal as evidence of repeated wildfires is in good agreement with palaeoclimatic interpretations for the Bahariya Formation. Based on palynological studies, a number of authors reconstructed a tropical warm and semi-arid climate during deposition of this formation (e.g. Abdel-Kireem et al. 1996; Ibrahim 2002). Such climatic conditions, with a marked and prolonged dry season, can promote the ignition and spread of wildfires (e.g. Scott et al. 2014), especially when the atmospheric oxygen concentration is assumed higher than today (see above).

In short, our data suggest that these wildfires probably affected different vegetation types, maybe extending into 


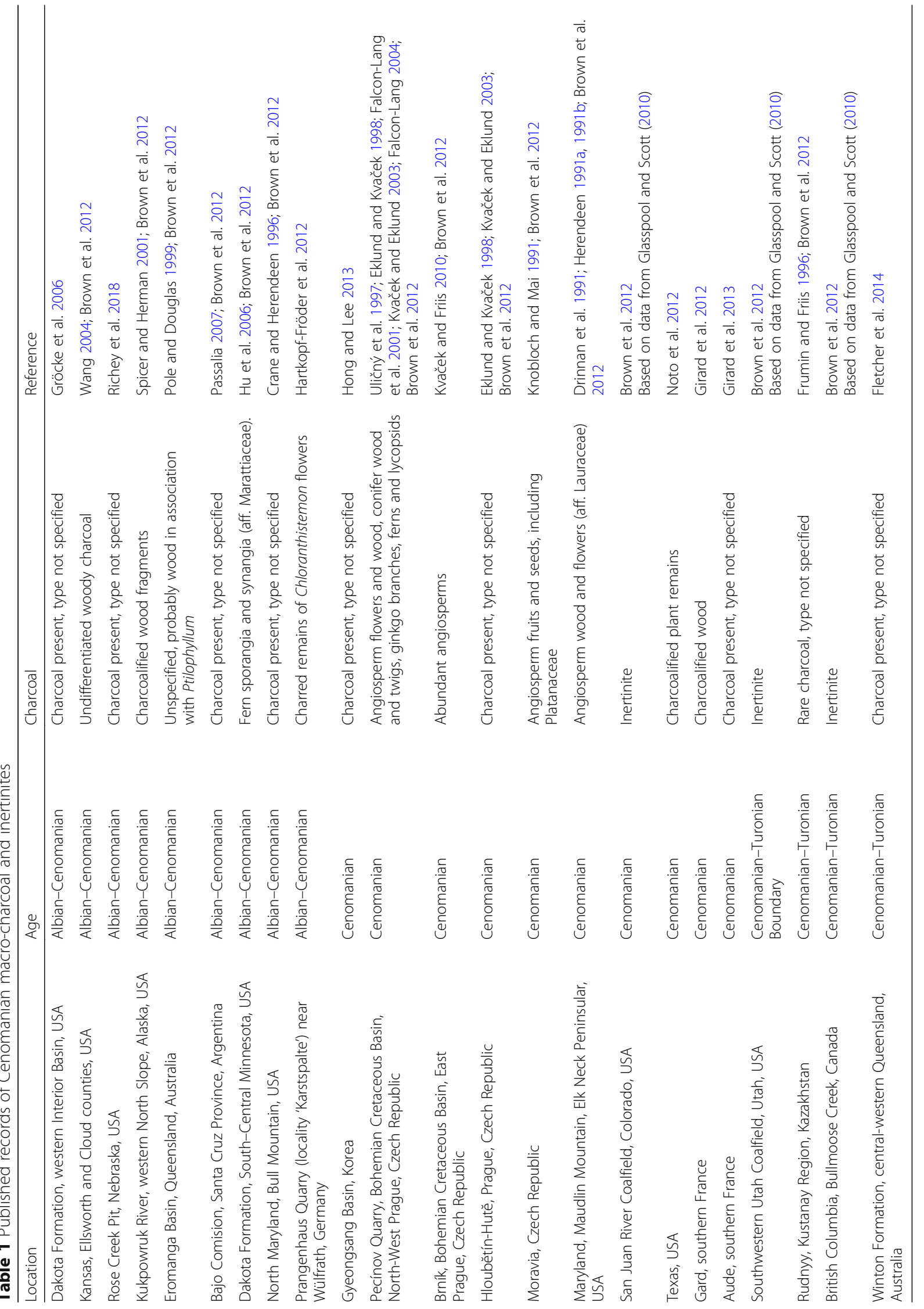




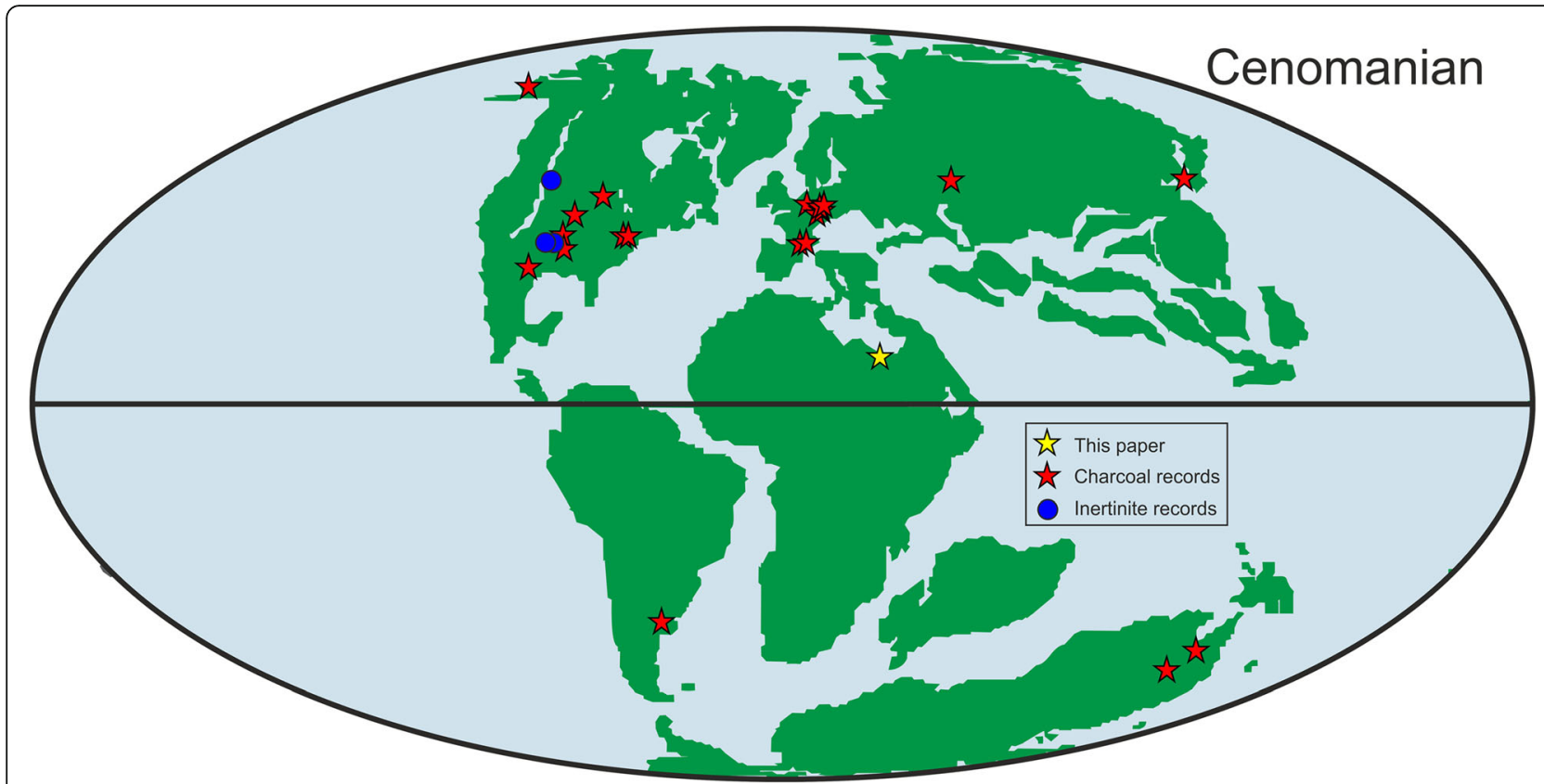

Fig. 8 Distribution map of published records of evidence for Cenomanian wildfires. Palaeogeography based on Scotese (2004)

the wet-endmember of coastal ecosystems, fern dominated mangroves (or mangrove-like vegetation), which were probably the habitat of Spinosaurus that has been reconstructed as a piscivorous and semiaquatic predator (e.g. Ibrahim et al. 2014).

\section{Conclusions}

Based on current data and interpretations, we can conclude that palaeo-wildfires repeatedly occurred during the deposition of the early Cenomanian Bahariya Formation at the Bahariya Oasis in Egypt, located at the northern shores of Gondwana during that time. Our analysis also indicates that different types of vegetation, including angiosperms, gymnosperms and ferns, were possibly affected by fires. In one charcoal bearing level (Chl 3), it seems that (mangrove-like) coastal vegetation, dominated by ferns comparable to Paradoxopteris/Weichselia reticulata, was subjected to such fires. Our data supplement the so far scarce record of Cenomanian wildfires on the southern continents, providing further evidence that during the early Late Cretaceous fires were a common type of disturbance on a global scale.

\section{Abbreviations}

Chl: Charcoal level; Dx: Sample number of samples taken at locality Gabal El Dist; SEM: Scanning Electron Microscope; SMB: Collection acronym: Senckenberg Museum Botany

\section{Acknowledgements}

The authors gratefully thank Claudia Franz (Senckenberg Forschungsinstitut und Naturmuseum Frankfurt) for technical assistance with SEM facilities, and Ahmed Gomaa (Mansoura University) for his help during the field work. H. El Atfy and T. Anan thank Department of Geology, Mansoura University for logistic support during field work at the Bahariya Oasis.
Authors' contributions

All authors read and approved the final manuscript.

\section{Funding}

D. Uhl and A. Jasper acknowledge the financial support by Coordenadoria de Aperfeiçoamento de Pessoal de Nível Superior - CAPES (A072/2013 and 8107-14-9), Conselho Nacional de Desenvolvimento Científico e Tecnológico - CNPq (444330/2014-3, 305436/2015-5), Brazil and Alexander von Humboldt Foundation (3.4-8151/18 025), Germany.

\section{Availability of data and materials}

All data are available from the authors. Material is available from the corresponding repositories, as stated in the material section.

\section{Competing interests}

The authors declare that they have no competing interests.

\section{Author details}

'Department of Geology, Faculty of Science, Mansoura University, Mansoura 35516, Egypt. 2Programa de Pós-Graduação em Ambiente e Desenvolvimento, PPGAD, Universidade do Vale do Taquari - Univates, Lajeado, Rio Grande do Sul, Brazil. ${ }^{3}$ Senckenberg Research Institute and Natural History Museum, 60325 Frankfurt am Main, Germany. ${ }^{4}$ Senckenberg Centre for Human Evolution and Palaeoenvironment, Tübingen University, 72076 Tübingen, Germany.

Received: 25 August 2018 Accepted: 24 May 2019

Published online: 26 August 2019

\section{References}

Abdel-Kireem, M.R., E. Schrank, A.M. Samir, and M.I.A. Ibrahim. 1996. Cretaceous palaeoecology, palaeogeography and palaeoclimatology of the northern Western Desert, Egypt. Journal of African Earth Sciences 22: 93-112.

Abu Hamad, A.M.B., B. Amireh, H. El Atfy, A. Jasper, and D. Uhl. 2016a. Fire in a Weichselia-dominated coastal ecosystem from the early cretaceous (Barremian) of the Kurnub group in NW Jordan. Cretaceous Research 66: 82-93. 
Abu Hamad, A.M.B., B. Amireh, A. Jasper, and D. Uhl. 2016b. New palaeobotanical data from the Jarash formation (Aptian-Albian, Kurnub group) of NW Jordan. The Palaeobotanist 65: 19-29.

Abu Hamad, A.M.B., A. Jasper, and D. Uhl. 2012. The record of Triassic charcoal and other evidence for palaeo-wildfires: Signal for atmospheric oxygen levels, taphonomic biases or lack of fuel? International Journal of Coal Geology 96-97: 60-71.

Alvin, K.L. 1974. Leaf anatomy of Weichselia based on fusainized material. Palaeont 17: 587-598.

Belcher, C.M., and V.A. Hudspith. 2017. Changes to cretaceous surface fire behaviour influenced the spread of the early angiosperms. Science 321: 1197-1200.

Belcher, C.M., and J.C. McElwain. 2008. Limits for combustion in low $\mathrm{O}_{2}$ redefine paleoatmospheric predictions for the Mesozoic. New Phytologist 213: 1521-1532.

Belcher, C.M., J.M. Yearsley, R.M. Hadden, J.C. McElwain, and G. Rein. 2010 Baseline intrinsic flammability of earths' ecosystems estimated from paleoatmospheric oxygen over the past 350 million years. PNAS 107: 22448-22453.

Bond, W.J., and A.C. Scott. 2010. Fire and the spread of flowering plants in the cretaceous. New Phytologist 188: 1137-1150.

Brown, S.A.E., A.C. Scott, I.J. Glasspool, and M.E. Collinson. 2012. Cretaceous wildfires and their impact on the earth system. Cretaceous Research 36: 162-190.

Carpenter, R.J., A.I. Holman, A.D. Abell, and K. Grice. 2016. Cretaceous fire in Australia: A review with new geochemical evidence, and relevance to the rise of the angiosperms. Australian Journal of Botany 64: 564-578.

Crane, P.R., and P.S. Herendeen. 1996. Cretaceous floras containing angiosperm flowers and fruits from eastern North America. Review of Palaeobotany and Palynology 90: 319-337.

Diessel, C.F. 2010. The stratigraphic distribution of inertinite. International Journal of Coal Geology 81: 251-268.

Dominik, W. 1985. Stratigraphie und Sedimentologie (Geochemie, Schwermineralanalyse) der Oberkreide von Bahariya und ihre Korrelation zum Dakhla-Becken (Western Desert, Ägypten). Berliner geowiss Abh A 62: 173.

dos Santos, Â.C.S., E. Celestino Holanda, V. de Souza, M. Guerra-Sommer, J. Manfroi, D. Uhl, and A. Jasper. 2016. Evidence of palaeo-wildfire from the late early cretaceous (Serra do Tucano formation, Aptian-Albian) of Roraima (North Brazil). Cretaceous Research 57: 46-49.

Drinnan, A.N., P.R. Crane, K.R. Pedersen, and E.M. Friis. 1991. Angiosperm flowers and tricolpate pollen of buxaceous affinity from the Potomac group (mid-cretaceous) of eastern North America. American Journal of Botany 78: 153-176.

Edwards, W.N. 1933. On the cretaceous fern Paradoxopteris and its connection with Weichselia. Annals of Botany 47: 317-341.

Eklund, H., and J. Kvaček. 1998. Lauraceous inflorescences and flowers from the Cenomanian of Bohemia (Czech Republic, Central Europe). International Journal of Plant Sciences 159: 668-686.

El Akkad, S., and B. Issawi. 1963. Geology and iron ore deposits of the Bahariya oasis. Geological Survey of Egypt 18: 301.

El Atfy, H. 2011. Cretaceous palynology of the GPTSW-7 well. Western Desert, Egypt: LAP LAMBERT Academic Publishing GmbH \& Co KG. ISBN 978-38465-3295-9.

El Atfy, H., P. Havlik, P.S. Krüger, J. Manfroi, A. Jasper, and D. Uhl. 2017. Prequaternary wood decay 'caught in the act' by fire - Examples of plantmicrobe-interactions preserved in charcoal from clastic sediments. Historical Biology. https://doi.org/10.1080/08912963.2017.1413101.

El Atfy, H., H. Sallam, A. Jasper, and D. Uhl. 2016. The first evidence of palaeo-wildfire from the late cretaceous (Campanian) of North Africa. Cretaceous Research 57: 306-310.

El-Saadawi, W., R. Osman, M.W. El-Faramawi, H. Bkhat, and M. Kamal-El-Din. 2016. On the cretaceous mangroves of Bahariya oasis, Egypt. Taeckholmia 36: 1-16.

Falcon-Lang, H.J. 2004. A new anatomically preserved ginkgoalean genus from the upper cretaceous (Cenomanian) of the Czech Republic Palaeontology 47: 349-366.
Falcon-Lang, H.J., J. Kvaček, and D. Ulicny. 2001. Fire-prone plant communities and palaeoclimate of a late cretaceous fluvial to estuarine environment, Pecínov quarry, Czech Republic. Geological Magazine 138: 563-576.

Fletcher, T.L., D.R. Greenwood, P.T. Moss, and S.W. Salisbury. 2014. Paleoclimate of the late cretaceous (Cenomanian-Turonian) portion of the Winton formation, Central-Western Queensland, Australia: New observations based on CLAMP and bioclimatic analysis. Palaios 29: 121-128.

Frumin, S.I., and E.M. Friis. 1996. Liriodendroid seeds from the late cretaceous of Kazakhstan and North Carolina, USA. Review of Palaeobotany and Palynology 94: 39-55.

Gerards, T., F. Damblon, B. Wauthoz, and P. Gerrienne. 2007. Comparison of cross-field pitting in fresh, dried and charcoalified softwoods. IAWA Journal 28: 49-60.

Girard, V., G. Breton, V. Perrichot, and M. Bilotte. 2013. The Cenomanian amber of Fourtou (Aude, southern France): Taphonomy and palaeoecological implications. Annales de Paléontologie 99: 301-315.

Girard, V., M. Philippe, M. Bamford, B. Gomez, and S. Ferry. 2012. Charcoalified wood from the Cenomanian of Gard (southern France): An insight into early angiosperm palaeoecology. Revista Españolade Paleontologia 27: 29-44.

Glasspool, I.J., and A.C. Scott. 2010. Phanerozoic atmospheric oxygen concentrations reconstructed from sedimentary charcoal. Nature Geoscience 3: 627-630.

Gröcke, D., B.L. Witzke, S.A. Robinson, R.M. Joeckel, D.F. Ufnar, and R.L. Ravn. 2006. Recognizing the Albian-Cenomanian (OAE1d) sequence boundary using plant carbon isotopes: Dakota formation, Western Interior Basin USA. Geology 34: 193-196.

Harris, T.M. 1958. Forest fire in the Mesozoic. Journal of Ecology 46: 447-453.

Harris, T.M. 1981. Burnt ferns from the English Wealden. Proceedings of the Geologists' Association 92: 47-58.

Hartkopf-Fröder, C., J. Rust, T. Wappler, E.M. Friis, and A. Viehofen. 2012. Midcretaceous charred fossil flowers reveal direct observation of arthropod feeding strategies. Biology Letters 8: 295-298.

Herendeen, P.S. 1991a. Lauraceous wood from the mid-cretaceous Potomac group of eastern North America: Paraphyllanthoxylon marylandense sp. nov. Review of Palaeobotany and Palynology 69: 277-290.

Herendeen, P.S. 1991b. Charcoalified angiosperm wood from the cretaceous of eastern North America and Europe. Review of Palaeobotany and Palynology 70: 225-239.

Hirmer, M. 1925. Ergebnisse der Forschungsreisen Prof. E. Stromers in den Wüsten von Ägypten IV. Die fossilen Floren Ägyptens. 3. Die fossilen Pflanzen Ägyptens. D. Filicales. Abh Bayer Akad Wiss, Math-nat Abt Neue Folge 30 (3): 1-18.

Hirmer, M. 1927. Handbuch der Palaobotanik. Band I. Thallophyta, Bryophyta Pteridophyta, 708. München \& Berlin: R. Oldenbourg.

Hong, S.K., and Y.I. Lee. 2013. Contributions of soot to $\delta^{13} \mathrm{C}$ of organic matter in cretaceous lacustrine deposits, Gyeongsang Basin, Korea: Implication for paleoenvironmental reconstructions. Palaeogeography, Palaeodlimatology, Palaeoecology 371: 54-61.

Hu, S., D.L. Dilcher, H. Schneider, and D.M. Jarzeny. 2006. Eusporangiate ferns from the Dakota formation, Minnesota, USA. International Journal of Plant Sciences 167: 579-589.

Ibrahim, M.I.A. 2002. Late Albian-middle Cenomanian palynofacies and palynostratigraphy, Abu Gharadig-5 well, Western Desert, Egypt. Cretaceous Research 23: 775-788.

Ibrahim, N., P.C. Sereno, C. Dal Sasso, S. Maganuco, M. Fabbri, D.M. Martill, S. Zouhri, N. Myhrvold, and D.A. Iurino. 2014. Semiaquatic adaptations in a giant predatory dinosaur. Science 345: 1613-1616.

Jasper, A., D. Agnihotri, R. Tewari, R. Spiekermann, E.F. Pires, Á.A.S. da Rosa, and D. Uhl. 2017. Fires in the mire: Repeated fire events in early Permian 'peat forming' vegetation of India. Geological Journal 52: 955-569.

Jones, T.P., and W.G. Chaloner. 1991. Fossil charcoal, its recognition and palaeoatmospheric significance. Palaeogeography, Palaeoclimatology, Palaeoecology 97: 39-50.

Klitzsch, E., and M. Hermina. 1989. The Mesozoic. In Stratigraphic lexicon and explanatory notes to the geological map of Egypt 1: 500,000, ed. M. Hermina, E. Klitzsch, and F.K. List, 77-139. Cairo: Conoco Inc. 
Knobloch, E., and D.H. Mai. 1991. Evolution of middle and upper cretaceous floras in central and western Europe. Geologisches Jahrbuch A 134: 257-270.

Koeniguer, J.C. 1966. Étude paléophytogéographique du continental intercalaire de L'Afrique Nord-Équatoriale. Sur de nouveaux échantillons du genre Paradoxopteris. Memoirs of the Geological Society of France 105: 100-112.

Kräusel, R. 1924. Ergebnisse der Forschungsreisen Prof. E. Stromers in den Wüsten von Ägypten IV. Die fossilen Floren Ägyptens. 3. Die fossilen Pflanzen Ägyptens. A. Fungi et Algae, B. Gymnospermae, Coniferae, C. Angiospermae, Monocotyledoneae. Abh Bayer Akad Wiss, Math-nat Abt Neue Folge 30: 28-48.

Kräusel, R. 1939. Ergebnisse der Forschungsreisen Prof. E. Stromers in den Wüsten von Ägypten IV. Die fossilen Floren Ägyptens. 3. Die fossilen Pflanzen Ägyptens. E. Vorbemerkungen, F. Nachträge zu B-D, G. Angiospermae Dicotyledoneae, $H$. Allgemeine Betrachtungen, J. Bestimmungstabelle für die fossilen Laubhölzer Ägyptens und einiger anderer afrikanischer Fundorte, K. Schriftenverzeichnis, L. Tafelerklärungen. Abh Bayer Akad Wiss, Math-nat Abt Neue Folge 47: 1-140.

Kvaček, J., and H. Eklund. 2003. A report on newly recovered reproductive structures from the Cenomanian of Bohemia (Central Europe). Internationl Journal of Plant Sciences 164: 1021-1039.

Kvaček, J., and E.M. Friis. 2010. Zlatkocarpus gen. Nov, a new angiosperm reproductive structure with monocolpate-reticulate pollen from the late cretaceous (Cenomanian) of the Czech Republic. Grana 49: 115-127.

Lacovara, K.J., J.R. Smith, J.B. Smith, and M.C. Lamanna. 2003. The ten thousand islands coast of Florida: A modern analog to low-energy mangrove coasts of cretaceous epeiric seas. Proceedings of the 5th International Conference of Coastal Sedimentology 5: 1773-1784.

Lejal-Nicol, A. 1987. Flores nouvelles du Paléozoiques et de de Mésozoique d'Egypte et du Soudan septentrional. Berliner geowiss Abh A 75: 151-248.

Lejal-Nicol, A. 1990. Fossil Flora. In The geology of Egypt, ed. R. Said. Rotterdam: Published for the Egyptian General Petroleum Corporation Conoco Hurghada Inc. and Repsol Exploracion S.A.A.A. Balkema.

Lejal-Nicol, A., and W. Dominik. 1990. Sur la paleoflore a Weichseliaceae et a angiospermes du Cenomanien de la region de Bahariya (Egypte du Sud-Ouest). Berliner geowiss Abh A 120: 957-991.

Lima, F.J., E.F. Pires, A. Jasper, D. Uhl, A.A.F. Saraiva, J.M. Sayao. 2019. Fire in the paradise: evidence of repeated palaeo-wildfires from the Araripe Fossil Lagerstätte (Araripe Basin, Aptian-Albian), Northeast Brazil. Palaeobiodiversity and Palaeoenvironments. 99: 367-378. https://doi.org/1 0.1007/s12549-018-0359-7.

Manfroi, J., T. Lindner Dutra, S.C. Gnaedinger, D. Uhl, and A. Jasper. 2015. The first report of a Campanian palaeo-wildfire in the West Antarctic peninsula. Palaeogeography, Palaeoclimatology, Palaeoecology 418: 12-18.

Martill, D.M., R.F. Loveridge, B.A.R. Mohr, and E. Simmonds, (2012) A wildfire origin for terrestrial organic debris in the Cretaceous Santana Formation Fossil Lagerstätte (Araripe Basin) of north-east Brazil. Cretaceous Research 34: 135-141.

Muir, R.A., E.M. Bordy, and R. Prevec. 2015. Lower cretaceous deposit reveals first evidence of a post-wildfire debris flow in the Kirkwood formation, Algoa Basin, eastern cape, South Africa. Cretaceous Research 56: 161-179.

Nothdurft, W., J.B. Smith, M.C. Lamanna, K.J. Lacovara, J.C. Poole, and J.R. Smith. 2002. The lost dinosaurs of Egypt, 242. New York: Random House.

Noto, C.R., D.J. Main, and S.K. Drumheller. 2012. Feeding traces and paleobiology of a cretaceous (Cenomanian) crocodyliform: Example from the woodbine formation of Texas. Palaios 27: 105-115.

Passalia, M.G. 2007. A mid-cretaceous flora from the Kachaike formation, Patagonia, Argentina. Cretaceous Research 28: 830-840.

Pole, M., Y. Wang, C. Dong, X. Xie, N. Tian, L. Li, N. Zhou, N. Lu, A. Xie, and X. Zhang. 2018. Fires and storms - A Triassic-Jurassic transition section in the Sichuan Basin, China. Palaeobiodiversity and Palaeoenvironments 98: 29-47.

Pole, M.S., and J.G. Douglas. 1999. Bennettitales, Cycadales and Ginkgoales from the mid cretaceous of the Eromanga Basin, Queensland, Australia. Cretaceous Research 20: 523-538.

Potonié, R. 1929. Spuren von Wald- und Moorbränden in Vergangenheit und Gegenwart. Jahrbuch der Preussischen Geologischen Landesanstalt 49: 1184-1203.
Retallack, G., and D.L. Dilcher. 1981. A coastal hypothesis for the dispersal and rise to dominance of flowering plants. In Paleobotany, paleoecology, and evolution, 2, ed. K.J. Niklas, 27-77. New York: Praeger.

Richey, J.D., G. Upchurch, I.P. Montañez, B.H. Lomax, M.B. Suarez, N.M.J. Crout, R.M. Joeckel, G.A. Ludvigson, and J.J. Smith. 2018. Changes in $\mathrm{CO}_{2}$ during ocean anoxic event $1 \mathrm{~d}$ indicate similarities to other carbon cycle perturbations. Earth and Planetary Science Letters 491: 172-182.

Said, R. 1962. The Geology of Egypt, 377. Rotterdam: Published for the Egyptian general Petroluem corporation Conoco Hurghada Inc. and Repsol Exploracion S. A. A. A. Balkema.

Schaal, S. 1984. Oberkretazische Osteichthyes (Knochenfische) aus dem Bereich von Bahariya und Kharga, Ägypten, und ihre Aussagen zur Paläökologie und Stratigraphie. Berliner geowiss Abh A 53: 79.

Schuster, J. 1930. Ein Holmasandstein-Geschiebe mit strukturhaltiger Weichselia aus der Umgebung von Berlin. Neues Jahrbuch für Mineralogie, Geologie und Paläontologie 64B: 61-78.

Schweitzer, C.E., K.J. Lacovara, J.B. Smith, M.C. Lamanna, M.A. Mandela, and Y. Attia. 2003. Mangrove-dwelling crabs (Decapoda: Brachyura: Necrocarcinidae) associated with dinosaurs from the upper cretaceous (Cenomanian) of Egypt. Journal of Paleontology 77: 888-894.

Scotese, C.R. 2004. A continental drift flipbook. The Journal of Geology 112: 729-741.

Scott, A.C. 2000. The pre-quaternary history of fire. Palaeogeography, Palaeoclimatology, Palaeoecology 164: 281-329.

Scott, A.C. 2010. Charcoal recognition, taphonomy and uses in palaeoenvironmental analysis. Palaeogeography, Palaeoclimatology, Palaeoecology 291: 11-39.

Scott, A.C., D.M.J.S. Bowman, W.J. Bond, S.J. Pyne, and M.E. Alexander. 2014. Fire on Earth: An introduction, 413. Wiley Blackwell: Chichester.

Sender, L.M., U. Villanueva-Amadoz, D. Pons, J.B. Diez, and J. Ferrer. 2015. Singular taphonomic record of a wildfire event from middle Albian sites of Escucha formation in northeastern of Spain. Historical Biology 27: 442-452.

Shinaq, R., and K. Bandel. 1998. The flora of an estuarine channel margin in the early cretaceous of Jordan. Freiberger Forschungsh C 474: 39-57.

Smith, J.B., M.C. Lamanna, K.J. Lacovara, P. Dodson, J.R. Smith, J.C. Poole, R. Giegengack, and Y. Attia. 2001. A giant sauropod dinosaur from an upper cretaceous mangrove deposit in Egypt. Science 292: 1704-1706.

Spicer, R.A., and A.B. Herman. 2001. The Albian-Cenomanian flora of the Kukpowruk River, western north slope, Alaska: Stratigraphy, palaeofloristics, and plant communities. Cretaceous Research 22: 1-40.

Stromer, E. 1914. Ergebnisse der Forschungsreisen Prof. E. Stromers in den Wüsten Ägyptens, I. Die Topographie und Geologie der Strecke Ghraq Baharije. Abh Bayer Akad Wiss, Math-nat Abt Neue Folge 26: 1-78.

Stromer, E. 1915. Ergebnisse der Forschungsreisen Prof. E. Stromers in den Wüsten Ägyptens, II. Wirbeltier-Reste der Baharijestufe (unterstes Cenoman), 3. Das Original des Theropoden Spinosaurus aegyptiacus. Abh Bayer Akad Wiss, Math-nat Abt Neue Folge 28: 1-32.

Stromer, E. 1931. Ergebnisse der Forschungsreisen Prof. E. Stromers in den Wüsten Ägyptens, II. Wirbeltier-Reste der Baharijestufe (unterstes Cenoman), 10. Ein Skelett-Rest von Carcharodontosaurus nov. gen. Abh Bayer Akad Wiss, Math-nat Abt Neue Folge 9: 1-23.

Stromer, E. 1932. Ergebnisse der Forschungsreisen Prof. E. Stromers in den Wüsten Ägyptens, II. Wirbeltier-Reste der Baharijestufe (unterstes Cenoman), 11. Sauropoda. Abh Bayer Akad Wiss, Math-nat Abt Neue Folge 10: 1-21.

Stromer, E. 1936. Ergebnisse der Forschungsreisen Prof. E. Stromers in den Wüsten Ägyptens, VII. Baharîje-Kessel und -Stufe mit deren Fauna und Flora eine ergänzende Zusammenfassung. Abh Bayer Akad Wiss, Mathnat Abt Neue Folge 33: 3-102.

Tahoun, S.S., and O. Mohamed. 2013. Palynology and genetic sequence stratigraphy of the reservoir rocks (Cenomanian, Bahariya formation) in the Salam oil field, North Western Desert, Egypt. Cretaceous Research 45: 342-351.

Uličný, D., J. Kvaček, M. Svobodová, and L. Spicáková. 1997. High-Frequency Sea-level fluctuations and plant habitats in Cenomanian fluvial to estuarine succession: Pecínov quarry, Bohemia. Palaeogeography, Palaeoclimatology, Palaeoecology 136: 165-197. 
Wang, X. 2004. Plant cytoplasm preserved by lightning. Tissue and Cell 36: $351-360$.

Werner, C. 1989. Die Elasmobranchier-Fauna des Gebel Dist Member der Bahariya Formation (Obercenoman) der Oase Bahariya, Ägypten. Palaeo Ichthyolog 5: 112.

Werner, C. 1990. Biostratigraphical results of investigations on the Cenomanian elasmobranchian fauna of Bahariya oasis, Egypt. Berliner geowiss Abh A 120: 943-956.

\section{Publisher's Note}

Springer Nature remains neutral with regard to jurisdictional claims in published maps and institutional affiliations.

\section{Submit your manuscript to a SpringerOpen ${ }^{\mathcal{O}}$ journal and benefit from:}

- Convenient online submission

- Rigorous peer review

- Open access: articles freely available online

High visibility within the field

- Retaining the copyright to your article

Submit your next manuscript at $\boldsymbol{\nabla}$ springeropen.com 